\title{
PEMETAAN DAN PENGARUH KEBISINGAN TERHADAP KELELAHAN KERJA KARYAWAN PADA BAGIAN FIBERLINE DI INDUSTRI PEMBUATAN BUBUR KERTAS
}

\author{
Trisna, Cut Ita Erliana, Renny Lestari \\ Jurusan Teknik Industri, Fakultas Teknik, Universitas Malikussaleh \\ Jl. Batam Kampus Bukit Indah, Blang Pulo, Muara Satu, Lhokseumawe \\ E-mail : trisna@unimal.ac.id
}

\begin{abstract}
Abstrak
Manpower is an element that is dealing directly with the various consequences of industrial activities undertaken. Unqualified physical work environment such as noise that has exceeded the NAV is one of the examples faced by the workforce in the workplace. One of the activities that produce noise is the activity in the fiberline department in the pulp making industry which is the pulp making area. This study aims to map the noise and its effect on employee fatigue in the pulp making industry in the fiberline department. Research stages include noise measurement, noise mapping, filling out questionnaires by employees about work fatigue, calculation of questionnaire results, determining the effect of noise and work fatigue with regression analysis, and correlation determination. The noise mapping results at 30 point measurements indicate that the bleaching and pulp engine border areas exceed the safe threshold noise. Regression analysis results show the higher the noise level, the higher the level of work fatigue in employees. The result of correlation analysis is known that the correlation is positive or strongly correlated which shows that the effect of noise on fatigue is very strong. The noise mapping results can be known which area exceeds the noise threshold, so the company can anticipate the negative impact, as well as the strong relationship between noise and work fatigue.
\end{abstract}

Kata kunci : Kebisingan, Kelelahan, pemetaan kebisingan, Regresi, Korelasi

\section{Pendahuluan}

Tenaga kerja mempunyai peranan yang sangat penting sebagai penggerak roda pembangunan nasional khususnya yang berkaitan dengan sektor industri. Selain itu tenaga kerja adalah unsur yang langsung berhadapan dengan berbagai akibat dari kegiatan industri, sehingga sudah seharusnya kepada tenaga kerja diberikan perlindungan dan pemeliharaan kesehatan. Lingkungan kerja fisik yang tidak memenuhi syarat seperti bising yang telah melebihi nilai ambang batas $(\mathrm{NAB}>85 \mathrm{~dB})$ merupakan salah satu faktor yang dapat menimbulkan kelelahan. Berdasarkan Keputusan Menteri Kesehatan No.1405/MENKES/SK/XI/2002, bising merupakan suara yang tidak dikehendaki yang dapat mengganggu kesehatan.

PT. XYZ merupakan perusahan yang bergerak di bidang pembuatan bubur kertas yang mana pada proses produksinya menimbulkan kebisingan akibat operasi mesin-mesin. Salah satu kegiatan yang menghasilkan kebisingan adalah pada departmen fiberline yang merupakan area pembuatan bubur kertas. Departmen ini memiliki 4 bagian, yaitu digester, washing, bleaching dan pulp machine. Kebisingan yang ditimbulkan dari mesin-mesin yang beroperasi menimbulkan sulitnya berkomunikasi antara sesama karyawan, sehingga dapat mengganggu sistem pendengaran dan meningkatkan kelelahan kerja pada karyawan. 
Beberapa penelitian sebelumnya tentang kebisingan pada lingkungan kerja antara lain dilakukan oleh Kholik dan Krishna (2012) yang menganalisis tingkat kebisingan peralatan proses produksi terhadap kinerja karyawan pada unit power plant. Penelitian Ardiansyah dan Susihono (2014) menunjukkan bahwa adanya pengaruh kebisingan terhadap tekanan darah dan stres kerja. Budiyanto and Pratiwi (2015) membuktikan adalanya hubungan kebisingan dan lama kerja terhadap terjadinya stres kerja pada pekerja di pabrik tenun.

Warningsih (2006) memetakan kebisingan pada bandar udara yang mana sudah melewati baku mutu kebisingan untuk pemukiman yaitu antara 74-104 dB. Emrinaldi (2015) melakukan pemetaan tingkat kebisingan pada pabrik pengolah kelapa sawit dengan metode grid yang mana dari hasil pengukuran terdapat beberapa titik melebihi ambang batas aman $85 \mathrm{~dB}$.

Pada penelitian sebelumnya menunjukkan bahwa adanya pengaruh kebisingan terhadap tingkat stres dan kelelahan kerja pada beberapa proses produksi di suatu industri. Pemetaan dan pengaruh kebisingan pada penelitian sebelumnya dilakukan secara parsial. Hal ini menjadi motivasi kami untuk memetakan kebisingan dan menganalisis pengaruhnya terhadap kelelahan pada karyawan pada industri pembuatan bubur kertas khususnya bagian fiberline.

Tujuan penelitian ini adalah untuk memetakan kebisingan pada bagian fiberline industri pembuatan bubur kertas dan menganalisis pengaruhnya terhadap kelelahan pada karyawan

\section{Tinjauan Pustaka}

\section{Kebisingan}

Menurut Keputusan Menteri Tenaga Kerja Nomor: KEP-51/MEN/1999, kebisingan adalah semua suara yang tidak dikehendaki yang bersumber dari alat-alat proses produksi dan atau alat-alat kerja yang pada tingkat tertentu dapat menimbulkan gangguan pendengaran. Kebisingan dapat menyebabkan gangguan indera pendengaran, gangguan komunikasi, gangguan tidur, gangguan pelaksanaan tugas, perasaan tidak senang, dan gangguan faal tubuh yang menyerang sistem keseimbangan dan sistem kardiovaskular (Tambunan, 2005). Secara umum kebisingan dapat diartikan sebagai suara yang merugikan terhadap manusia dan lingkungannya termasuk pada ternak, satwa liar dan sistem di alam (Soeratmo, 1988).

Nilai ambang batas kebisingan adalah 85 $\mathrm{dB}$ yang dianggap aman untuk sebagian besar tenaga kerja bila bekerja 8 jam/hari atau 40 jam/minggu. Nilai ambang batas untuk kebisingan di tempat kerja adalah intensitas tertinggi dan merupakan rata-rata yang masih dapat diterima tenaga kerja tanpa mengakibatkan hilangnya daya dengar yang tetap untuk waktu terusmenerus tidak lebih dari dari 8 jam sehari atau 40 jam seminggunya.

\section{Tingkat Kebisingan Siang Hari}

Pernyataan tingkat kebisingan siang hari merupakan model tingkat kebisingan equivalent yang dipergunakan untuk menyatakan tingkat kebisingan pada siang hari. Sesuai ketentuan dari menteri negara lingkungan hidup, data tingkat kebisingan ekuivalen pada setiap titik dan waktu diklasifikasi dalam 2 jenis, yakni tingkat kebisingan siang hari dan malam hari. Interval waktu sesuai peraturan KEP-48/MENLH/11/1996 dengan waktu pengukuran dilakukan selama aktivitas 24 jam (LSM) dengan cara pada siang hari tingkat aktifitas yang paling tinggi selama 16 jam (LS) pada selang waktu 06.0022.00. Tingkat kebisingan yang mewakili waktu siang hari diperoleh dari pengukuran kebisingan selama 14 jam pada pukul 09:00, 11:00, 13:00, 15:00, 17:00 dan 21:00. Model matematis untuk tingkat kebisingan siang hari disajikan menurut persamaan:

$$
\begin{aligned}
& \text { Ls } \quad=\quad 10 \quad \log \\
& \left\{f_{1} 10^{0.1 L_{1}}+f_{2} 10^{0.1 L_{2}}+\ldots . f_{n} 10^{0.1 L_{n}}\right\} \\
& d B A
\end{aligned}
$$


di mana,

Ls = Tingkat kebisingan siang hari

$F_{n}=$ Fraksi waktu ke-n

Ln = Tingkat kebisingan ke-n

\section{Korelasi}

\section{Pemetaan Kebisingan}

Dalam bidang industri biasanya noise mapping bertujuan untuk dijadikan pedoman alam mengabil langkah-langkah SMK3 (Sistem Manajemen Kesehatan dan Keselamatan Kerja) berdasarkan peta yang dibuat, serta untuk mengetahui dimana lokasi yang tepat untuk pemakaian APP (ear muff atau ear plug) berdasarkan sound intensity (Emrinaldi, 2015).

\section{Kelelahan Kerja}

Kelelahan adalah keadaan yang disertai penurunan efisiensi dan ketahanan dalam bekerja. Kata kelelahan menunjukkan keadaan yang berbeda-beda, tetapi semuanya berakibat kepada pengurangan kapasitas kerja dan ketahanan tubuh. Jadi efek pajanan bising pada tenaga kerja adalah pengaruhnya terhadap kesehatan dan kinerjanya. Beberapa diantaranya adalah gangguan pendengaran, komunikasi, kelelahan, respon fisiologis dan psikologis (Tarwaka, 2010). Kelelahan menunjukkan keadaan yang berbeda-beda, tetapi semuanya berakibat kepada pengurangan kapasitas kerja dan ketahanan tubuh.

\section{Regresi Linear}

Regresi linear adalah alat statistik yang dipergunakan untuk mengetahui pengaruh antara satu atau beberapa variabel terhadap satu buah variabel. Variabel yang mempengaruhi sering disebut variabel bebas, variabel independen atau variabel penjelas. Variabel yang dipengaruhi sering disebut dengan variabel terikat atau variabel dependen. Regresi linear hanya dapat digunakan pada skala interval dan ratio (Harinaldi, 2005).

Rumus regresi linear sederhana $\mathrm{Y}^{\prime}=\mathrm{a}+\mathrm{bX}$

Korelasi sederhana merupakan suatu teknik statistik yang dipergunakan untuk mengukur kekuatan hubungan 2 variabel dan juga untuk dapat mengetahui bentuk hubungan antara 2 variabel tersebut dengan hasil yang sifatnya kuantitatif. Kekuatan hubungan antara 2 variabel yang dimaksud disini adalah apakah hubungan tersebut erat, lemah ataupun tidak erat sedangkan bentuk hubungannya adalah apakah bentuk korelasinya linear positif ataupun linear negatif. Untuk melihat seberapa erat hubungan antar variabel, kita dapat melihatnya dari pedoman derajat hubungan seperti pada Tabel 1 .

Tabel 1. Derajat Pedoman Hubungan

\begin{tabular}{lll}
\hline No & \multicolumn{1}{c}{$\begin{array}{c}\text { Nilai korelasi } \\
\text { Pearson }\end{array}$} & \multicolumn{1}{c}{ Keterangan } \\
\hline 1 & $0,00 \mathrm{~s} / \mathrm{d} 0,20$ & Tidak ada korelasi \\
2 & $0,21 \mathrm{~s} / \mathrm{d} 0,40$ & Korelasi lemah \\
3 & $0,41 \mathrm{~s} / \mathrm{d} 0,60$ & Korelasi sedang \\
4 & $0,61 \mathrm{~s} / \mathrm{d} 0,80$ & Korelasi kuat \\
5 & $0,81 \mathrm{~s} / \mathrm{d} 1,00$ & Korelasi sempurna \\
\hline
\end{tabular}

\section{Metode Penelitian}

Penelitian ini dilakukan pada perusahaan pembuatan bubur kertas di Kecamatan Parmaksian, Kabupaten Toba, Sumatera Utara. Objek penelitian ini adalah tingkat kebisingan dan tingkat kelelahan pada karyawan di departemen fiberline di PT. XYZ. Waktu pelaksanaan penelitian dilaksanakan secara keseluruhan dari bulan Juni-Juli 2017. Populasi penelitian ini adalah karyawan pada bagian fiberline yang bekerja pada shift I dan shift II yang berjumlah 38 tenaga kerja, dengan sampel sebanyak 30 tenaga kerja dibagi ke dalam 4 bagian yaitu area digester, washing, bleaching, dan pulp machine.

Tahapan-tahapan penelitian meliputi:

1. Pengukuran kebisingan siang hari 
Perhitungan ini perlu dilakukan untuk mengetahui tingkat kebisingan siang hari.

2. Perhitungan rata-rata tingkat kebisingan

Perhitungan ini perlu diketahui untuk melihat rata-rata tingkat kebisingan siang hari dalam rentang waktu yang telah ditentukan.

3. Pemetaan kebisingan (noise mapping)

Pemetaan kebisingan (noise mapping) adalah pemetaan kebisingan yang menggambarkan distribusi tingkat kebisingan pada suatu lingkup kerja (workplace) yang menggunakan software surfer 8.0.

4. Perhitungan hasil kuesioner

Kuesioner yang telah diisi oleh karyawan, kemudian dijumlahkan hasil skor berdasarkan tingkat kelelahan yang dirasakan oleh karyawan. Perhitungan hasil kuesioner ini dilakukan secara manual.

5. Penentuan antara variabel bebas dan variabel terikat dengan regresi linear Analisis regresi dilakukan untuk mengukur pengaruh variabel bebas terhadap variabel terikat. Pengukuran pengaruh ini melibatkan satu variabel bebas/independen (X) dan variabel terikat/dependen (Y). Pada penelitian ini variabel bebas adalah kebisingan dan variabel terikat adalah kelelahan kerja..

6. Menentukan korelasi

Analisis korelasi dilakukan untuk mengukur kekuatan hubungan antara 2 variabel yaitu antara variabel bebas (kebisingan) dengan variabel terikat (kelelahan kerja). Kekuatan hubungan antara 2 variabel yang dimaksud adalah apakah hubungan antara kebisingan dengan kelelahan kerja erat, lemah ataupun tidak erat.

\section{Hasil dan Pembahasan}

\section{Pengukuran Tingkat Kebisingan}

Pengukuran tingkat kebisingan pada departemen fiberline dilakukan di 30 titik pengukuran dengan menggunakan alat

ukur kebisingan Sound Level Meter (SLM) selama 14 jam dengan waktu pengukuran yang telah ditentukan. Rentang waktu pengukuran selama 5 hari. Rekapitulasi tingkat kebisingan Ls pada hari ke-1 untuk setiap titik pengukuran dapat dilihat pada Tabel 2.

Pengukuran kebisingan pada hari ke-2 sampai hari ke-5 dilakukan pada titik yang dan waktu yang sama. Dari data yang diperoleh, tingkat kebisingan siang hari pada pada hari ke-1 dengan titik pengukuran ke-1 adalah sebagai berikut:

$\begin{array}{ccccc} & \mathrm{L}_{1}=87,9 d B A & \mathrm{~L}_{3}= & 88,5 \\ d B A & & \mathrm{~L}_{5}=86,4 d B A & \\ & \mathrm{~L}_{2}=88 d B A & \mathrm{~L}_{4}= & 87,8 \\ d B A & & & \mathrm{~L}_{6}=85,1 d B A & \end{array}$

Maka diperoleh hasil perhitungan sebagai berikut:

$$
\begin{aligned}
& L s=10 \log \left\{f_{1} 10^{0.1 L_{1}}+f_{2} 10^{0.1 L_{2}}+\ldots . . f_{n} 10^{0.1 L_{n}}\right\} d B A \\
& \text { Ls } \quad=\quad 10 \quad \log \\
& \left\{\frac{2}{16} \cdot 10^{0.1 .1879}+\frac{2}{16} \cdot 10^{0.1 .188}+\frac{2}{16} \cdot 10^{0.1 .1885}+\frac{2}{16} \cdot 10^{0.1 .187 .8}+\frac{4}{16} \cdot 10^{0.1 .864}+\frac{2}{16} \cdot 10^{0.1 .18511}\right\} \\
& \text { Ls } \quad=\quad 10 \quad \log \\
& \left\{\frac{2}{16} \cdot 10^{8.79}+\frac{2}{16} \cdot 10^{8.8}+\frac{2}{16} \cdot 10^{8.85}+\frac{2}{16} \cdot 10^{8.78}+\frac{4}{16} \cdot 10^{8.64}+\frac{2}{16} \cdot 10^{8.51}\right\} \\
& L s=10 \log \{469335379,8\} \\
& L s=86,71 \mathrm{dBA}
\end{aligned}
$$

\begin{tabular}{|c|c|c|c|c|c|}
\hline $\begin{array}{c}\text { Titik } \\
\text { Pengukuran }\end{array}$ & $\begin{array}{c}\mathrm{LS} \\
(d B A)\end{array}$ & Lokasi & Titik & $\begin{array}{c}\mathrm{LS} \\
(\mathrm{dBA})\end{array}$ & Lokasi \\
\hline 1 & 86,71 & Digester & 16 & 88,07 & Bleaching \\
\hline 2 & 87,20 & Digester & 17 & 88,86 & Bleaching \\
\hline 3 & 87,03 & Digester & 18 & 90,51 & Bleaching \\
\hline 4 & 87,00 & Digester & 19 & 90,07 & Bleaching \\
\hline 5 & 86,31 & Digester & 20 & 89,61 & Bleaching \\
\hline 6 & 87,03 & Digester & 21 & 89,19 & Bleaching \\
\hline 7 & 87,22 & Digester & 22 & 90,04 & Bleaching \\
\hline 8 & 86,58 & Digester & 23 & 88,91 & Bleaching \\
\hline 9 & 87,70 & Washing & 24 & 89,49 & $\begin{array}{c}\text { Pulp } \\
\text { Machine }\end{array}$ \\
\hline 10 & 87,08 & Washing & 25 & 89,29 & $\begin{array}{c}\text { Pulp } \\
\text { Machine }\end{array}$ \\
\hline 11 & 87,25 & Washing & 26 & 90,90 & $\begin{array}{c}\text { Pulp } \\
\text { Machine }\end{array}$ \\
\hline 12 & 86,98 & Washing & 27 & 91,50 & $\begin{array}{c}\text { Pulp } \\
\text { Machine }\end{array}$ \\
\hline 13 & 87,77 & Washing & 28 & 90,52 & $\begin{array}{c}\text { Pulp } \\
\text { Machine }\end{array}$ \\
\hline 14 & 87,83 & Washing & 29 & 90,62 & $\begin{array}{c}\text { Pulp } \\
\text { Machine }\end{array}$ \\
\hline 15 & 87,99 & Washing & 30 & 88,89 & $\begin{array}{c}\text { Pulp } \\
\text { Machine }\end{array}$ \\
\hline
\end{tabular}

Tabel 2. Rekapitulasi tigkat kebisinga siang pada hari ke-1 
Perbandingan antara tingkat kebisingan siang hari dengan Nilai Ambang Batas (NAB) yang ditetapkan oleh pemerintah Kep-51/MEN/1999 dapat dilihat pada Gambar 1.

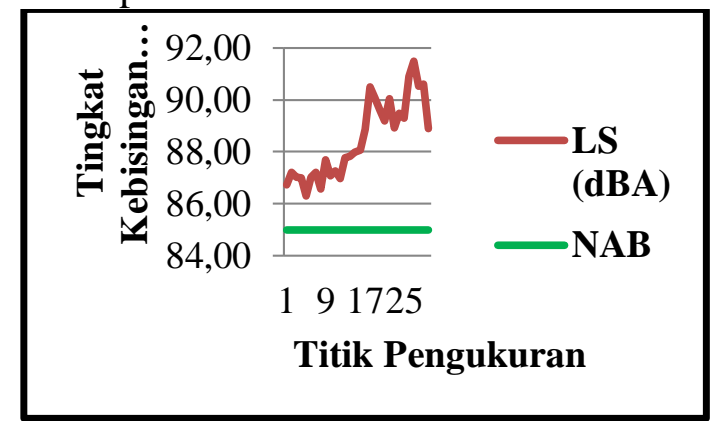

Gambar 1 Perbandingan antara $L s$ hari ke1 dengan (NAB)

Gambar 1 menunjukkan bahwa tingkat kebisingan siang hari $(L s)$ ke-30 titik pengukuran berada di atas Nilai Ambang Batas (NAB) yaitu $85 \mathrm{~dB}$.

Berdasarkan data tingkat kebisingan dilakukan pemetaan kebisingan dengan software surfer 8.0 pada setiap titik pengukuran. Hasil pemetaan Ls dari hari ke-1 dapat dilihat pada Gambar 2.

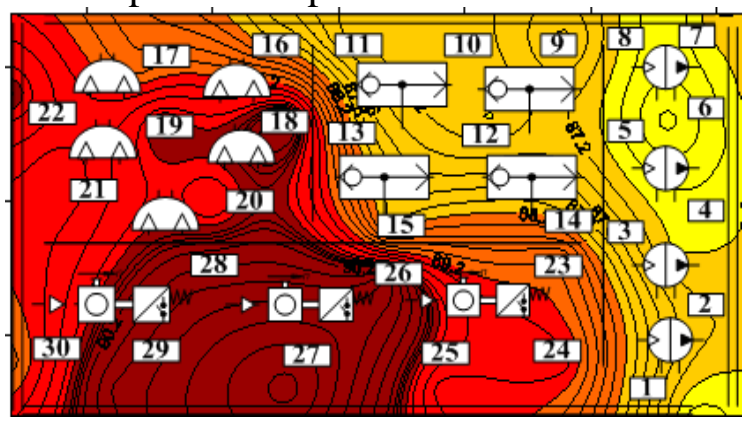

Gambar 2 Peta tingkat kebisingan $l s$ pada hari ke-1 dengan software surfer 8.0

Gambar 2 menunjukkan peta kebisingan dengan daerah-daerah yang wajib menggunakan ear plug yaitu diatas $85 d B A$. Kontur tersebut menunjukkan bahwa daerah yang paling bising berada pada area bleaching dan pulp machine.

\section{Pengukuran Kelelahan Kerja}

Kuesioner Alat Ukur Perasaan Kelelahan Kerja (KAUPK2) yang berisi 30 daftar pertanyaan yang berisi daftar-daftar gejala kelelahan kerja merupakan indikator adanya gejala kelelahan yang digunakan untuk mengukur tingkat kelelahan tenaga kerja. Pengukuran dilakukan terhadap tenaga kerja yang bekerja di area digester, washing, bleaching, dan pulp machine di departemen fiberline.

\section{Pengaruh Kebisingan dengan Kelelahan Kerja}

Berdasarkan hasil pengolahan data kebisingan dan kelelahan kerja, diperoleh data tingkat kebisingan siang hari (LS) dan tingkat kelelahan kerja pada tenaga kerja. Data tingkat kebisingan siang hari (LS) dan tingkat kelelahan tenaga kerja dapat dilihat pada Tabel 3.

Teknik pengolahan dan analisis data yang dilakukan untuk mengetahui ada atau tidak pengaruh tingkat kebisingan terhadap kelelahan kerja yaitu menggunakan analisis regresi linear sederhana. Hasil analisis regresi linear sederhana menunjukkan persamaan sebagai berikut:

$\mathrm{Y}^{\prime}=\mathrm{a}+\mathrm{bX}$

$Y^{\prime}=-250,03+3,253 X$

Koefisien (a) sebesar -250,03 artinya jika tingkat kebisingan $(\mathrm{X})$ nilainya adalah 0 maka kelelahan (Y) nilainya negatif yaitu sebesar $-250,03$. koefisien $b$ tingkat kebisingan (X) sebesar 3,253 artinya jika tingkat kebisingan mengalami kenaikan sebesar $1 \mathrm{~dB}$ maka kelelahan (Y) akan mengalami peningkatan sebesar 3,253. Koefisien (b) bernilai positif artinya terjadi hubungan positif antara tingkat kebisingan dengan kelelahan, sehingga semakin tinggi kebisingan maka semakin meningkat pula tingkat kelelahan.

Dari hasil perhitungan korelasi didapatkan $r=0,749$ bernilai positif, artinya terdapat hubungan atau korelasi yang kuat antara kebisingan dengan kelelahan kerja. Semakin tinggi tingkat kebisingan maka semakin tinggi tingkat kelelahan kerja pada karyawan. Koefisien determinasi $\mathrm{r}^{2}$ sebesar 0,561 yang mengandung pengertian bahwa variabel bebas (kebisingan) terhadap variabel terikat (kelelahan) adalah sebesar 56,1\% . 
kesehatan disarankan bagi karyawan untuk memakai ear plug.

Tabel 3. Tingkat Kebisingan Siang dan Tingkat Kelelahaan Kerja

\begin{tabular}{|c|c|c|}
\hline Responden & $\begin{array}{l}\text { Tingkat Kebisingan } \\
\text { Siang }(d B A)(\mathrm{X})\end{array}$ & $\begin{array}{c}\text { Tingkat } \\
\text { Kelelahan } \\
\text { Responden } \\
\text { (Y) }\end{array}$ \\
\hline 1 & 86,08 & 24 \\
\hline 2 & 87,01 & 27 \\
\hline 3 & 86,63 & 30 \\
\hline 4 & 86,95 & 20 \\
\hline 5 & 86,43 & 39 \\
\hline 6 & 86,79 & 41 \\
\hline 7 & 86,66 & 34 \\
\hline 8 & 86,68 & 30 \\
\hline 9 & 86,79 & 29 \\
\hline 10 & 87,09 & 41 \\
\hline 11 & 86,90 & 29 \\
\hline 12 & 86,74 & 30 \\
\hline 13 & 87,23 & 41 \\
\hline 14 & 87,50 & 36 \\
\hline 15 & 87,83 & 37 \\
\hline 16 & 88,89 & 43 \\
\hline 17 & 89,90 & 48 \\
\hline 18 & 89,96 & 42 \\
\hline 19 & 89,80 & 41 \\
\hline 20 & 90,12 & 45 \\
\hline 21 & 89,87 & 43 \\
\hline 22 & 89,71 & 42 \\
\hline 23 & 89,77 & 41 \\
\hline 24 & 89,77 & 38 \\
\hline 25 & 89,89 & 41 \\
\hline 26 & 90,53 & 42 \\
\hline 27 & 91,07 & 43 \\
\hline 28 & 90,12 & 43 \\
\hline 29 & 90,30 & 44 \\
\hline 30 & 89,23 & 43 \\
\hline
\end{tabular}

\section{Kesimpulan}

Hasil pemetaan kebisingan dapat diketahui daerah mana yang melebihi ambang batas kebisingan, sehingga pihak perusahaan dapat mengantisipasi dampak negatifnya. Tingkat kebisingan berpengaruh terhadap kelelahan kerja di mana sebagian besar karyawan kelelahan sedang dan kelelahan berat.

\section{Saran}

Untuk mengurangi dampak negatif kebisingan terhadap kelelahan dan

\section{UCAPAN TERIMA KASIH}

Terima kasih diucapkan pada Fakultas Teknik, Universitas Malikussaleh yang telah mendanai penelitian ini.

\section{Daftar Pustaka}

Ardiansyah, M. R., \& Susihono, W. (2014). Pengaruh Intensitas Kebisingan Terhadap Tekanan Darah dan Tingkat Stres Kerja. Jurnal Teknik Industri Untirta, 1(1).

Budiyanto, T., \& Pratiwi, E. Y. (2015). Hubungan Kebisingan dan Massa Kerja terhadap terjadinya Stres Kerja pada Pekerja di Bagian Tenun Agung Saputra tex Piyungan bantul Yogyakarta. Kes Mas: Jurnal Fakultas Kesehatan Masyarakat, 4(2), 126-135.

Emrinaldi, T. (2015). Pemetaan Tingkat Kebisingan yang Ditimbulkan oleh Mesin Pengolah Kelapa Sawit di PT. Tasma Puja, Kabupaten KamparRiau. Jurnal Online Mahasiswa (JOM) Bidang Matematika Dan Ilmu Pengetahuan Alam, 2(1), 138-143.

Harinaldi. (2005). Prinsip-Prinsip Statistik Untuk Teknik Dan Sains Jilid 1. Jakarta: Erlangga.

Kholik, H. M., \& Krishna, D. A. (2012). Analisis Tingkat Kebisingan Peralatan Produksi Terhadap Kinerja Karyawan. Jurnal Teknik Industri, 13(2), 194-200.

Soeratmo, F. G. (1988). Analisis mengenai dampak lingkungan. Gadjah Mada University Press.

Tambunan, S. T. B. (2005). Kebisingan di Tempat Kerja. Penerbit Andi: Yogyakarta.

Tarwaka, P. (2010). Ergonomi Industri Dasar-dasar pengetahuan ergonomi dan aplikasi di tempat kerja. Harapan Press. Surakarta.

Warningsih, T. (2006). Pemetaan Kebisingan dan Penilaian 
Masyarakat Terhadap Kebisingan

Banda r Udara (Studi Kasus Bandar

Udara Sultan Syarif Kasim II

Pekanbaru Riau. IPB (Bogor

Agricultural Institute). 